\title{
Art in Science
}

\section{Art In Science: The Stage of the Human Body-The Anatomical Theatre of Bologna}

\author{
Berardo Di Matteo MD, Vittorio Tarabella MA, \\ Giuseppe Filardo MD, PhD, Anna Viganò MA, \\ Patrizia Tomba MA, Laura Bragonzoni MA, \\ Maurilio Marcacci MD
}

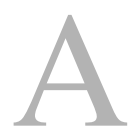

Note from the Column Editor,

Di Matteo and colleagues from the Rizzoli Orthopaedic Institute

Note from the Editor-in-Chief:

I am pleased to introduce the next installment of our "Art in Science" column coedited by Gary and Linda Friedlaender. Linda Friedlaender is the Curator of Education at the Yale Center for British Art; Gary is the Chair of the Department of Orthopaedics and Rehabilitation at Yale School of Medicine. In this month's column, Berardo Di Matteo MD and his colleagues from the Rizzoli Orthopaedic Institute and the University of Bologna, guide us as we tour the Anatomical Theatre of Bologna, one of the most prolific examples of art at the service of science.

The authors certify that they, or any members of their immediate families, have no funding or commercial associations (eg, consultancies, stock ownership, equity interest, patent/licensing arrangements, etc) that might pose a conflict of interest in connection with the submitted article. All ICMJE Conflict of Interest Forms for authors and Clinical Orthopaedics and Related Research ${ }^{\circledR}$ editors and board members are on file with the publication and can be viewed on request.

The opinions expressed are those of the writers, and do not reflect the opinion or policy of $C O R R^{\circledR}$ or the Association of Bone and Joint Surgeons ${ }^{\circledR}$.

The institution of one or more of the authors (BDM, VT, GF, AV, PT, LB, MM) has received, during the study period, funding from Italian State through "5 per mille (year 2011)" project. in Bologna, Italy share with us another extraordinary example of how medicine evolved in partnership with art. The University of Bologna is considered the oldest academic institution in the Western world, so it is no surprise that many of the finest examples of the evolution of scientific investigation and teaching originated in the expansive beauty of the Archiginnasio of Bologna. As Di Matteo and colleagues explain, this was the ancient stage upon which students observed the performances of teaching anatomy. It is serendipitous that this beautiful description of the $16^{\text {th }}$ century

B. Di Matteo MD ( $\varangle)$, V. Tarabella MA, G. Filardo MD, PhD, M. Marcacci MD Biomechanics Laboratory, II Clinic, Rizzoli Orthopaedic Institute, Via di Barbiano n. 1/10, 40136 Bologna, Italy e-mail: berardo.dimatteo@gmail.com

A. Viganò MA, P. Tomba MA Biblioteche Scientifiche Istituto Ortopedico Rizzoli, Rizzoli Orthopaedic Institute, Bologna, Italy

L. Bragonzoni MA

Department of Biomedical and Neuromotorial Science, University of Bologna, Bologna, Italy anatomy theatre follows our discussion of The Gross Clinic by American artist Thomas Eakins in the $19^{\text {th }}$ century [4], an example of the surgical theatre. This is an opportunity to compare the high drama carried out on these two stages, theatres set 300 years apart, both venues designed to be practical places for transmitting medical knowledge while also celebrating and aggrandizing the performances. Bravo!

- Gary E. Friedlaender MD, Linda K. Friedlaender BA, MS

Physicians are inherently captivated by human anatomy. It is in our very nature to seek out answers that can help unlock the human body's most hidden secrets. The journey to discovery generally begins in medical school, where the study of the human anatomy was once considered a cornerstone of medical education. The topic has been, to some degree, deemphasized through the years in order to make time for other priorities in a fast-paced, modern curriculum. The ways in which medical educators teach the subject is also evolving. Traditional dissection-based approaches have given way to more modern and 


\section{Art in Science}

practical teaching modalities such as self-directed, problem-based, and computer-assisted learning [9]. Although the days of watching live dissections are far from numbered, perhaps we will no longer need the "stage," equipped to accommodate a large number of eager students witnessing the "performance."

For medical students centuries ago, in the heart of Bologna, Italy, the stage was everything - a place to understand human anatomy, a place to witness the exaltation of life through the analysis of death, and a place to be captivated by science.

The stage was housed inside "theatres," some of which are considered true masterpieces of architecture. Their intrinsic beauty often surpassed the original purpose for which they were conceived. It is not uncommon for art and anatomy to share the same pathway [2,3], and this is indeed the case when we examine the Archiginnasio Palace of Bologna-home of the Anatomical Theatre of the Archiginnasio.

\section{The Archiginnasio Palace of Bologna}

The Archiginnasio Palace of Bologna, which was the main building of the ancient University of Bologna (the term "Archiginnasio" was used in the past to refer to the universities of Bologna and Rome), was erected in the second half of the $16^{\text {th }}$ century by the will of Pope Pius IV, patron saint of teachers and librarians. During his life, Pope Pius was a lavish philanthropist. Among his many deeds was giving the city of Bologna and its prestigious Studio Bolognese (the original name of the University of Bologna) a headquarters for higher studies, with a special focus on scientific and medical research. In 1637 , the already stunning Archiginnasio Palace was further enhanced by the addition of a new remarkable room devoted to anatomical learning, the so-called Teatro Anatomico (Anatomical Theatre), named for its peculiar shape resembling that of an ancient Roman amphitheatre (Fig. 1). It was designed by Antonio Paolucci, known as Antonio Levanti, one of the pupils of the Carracci family, the most illustrious family of artists in Bologna [7].

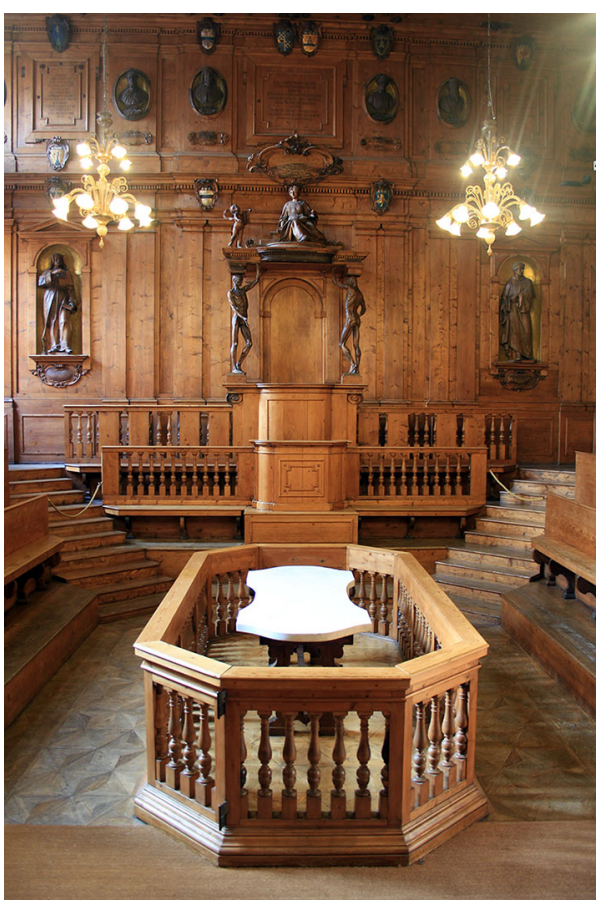

Fig. 1 A view of the Anatomical Theatre located in the Archiginnasio Palace of Bologna, Italy. Published with permission from Vittorio Tarabella MA. 


\section{Art in Science}

Erecting an anatomical theatre at the time was still a novel concept. Anatomical theatres first appeared in medical history in 1543 on the frontispiece of De Humani Corporis Fabrica Libri Septem [On the Fabric of the Human Body in Seven Books] by the Flemish anatomist, Andreas Vesalius [10]. He was a pioneer of a new way of teaching anatomy, which was no longer based on "ex-cathedra" lectures (a Latin expression indicating dogmatic and theoretical teachings) in traditional classrooms, but stood on more practical principles to allow a direct knowledge of anatomy through live dissections performed by the senior anatomist. It was a concept of true Renaissance, and the Studio Bolognese was remarkably quick to welcome this new way of teaching. Among the oldest universities in the Western world [6], the Studio Bolognese craved progress and advancement. Under these premises, the Archiginnasio Palace became host to one of the most incredible academic auditoria of the times.

\section{The Anatomical Theatre of Bologna}

Only a few anatomical theatres still survive, but the Anatomical Theatre of Bologna is surely one of the brightest examples of art at the service of science $[7,8]$. The room is covered in spruce wood, as was customary at that time of many teaching facilities. The characteristics of spruce wood allow for a more effective amplification of sound. There are two desks, one for the demonstrator and one for the lecturer. Above the lecturer, there is a canopy held up by two linden-wood statues. Those two statues are the representation and sublime synthesis of art and science-two bare and skinless men posed to show opposite views, front and back, of the complete male musculature (Fig. 2). They are called The Spellati (Skinned Men), and were created in 1734 by the great anatomist, painter, and sculptor Ercole Lelli (1702-1766).

More statues line the walls high above the two desks, portraying the most famous physicians and anatomists; they look down on teachers and students as a kind of "fathers" whose ideal presence might protect and inspire the new generations of medical practitioners. The statues are made of Lebanon cedar wood and, like before, the choice of wood was anything but random. In fact, according to the beliefs of the time, this particular aromatic tree was thought to contain special properties that fight against disease.

The ceiling (Fig. 3) is another massive piece of art celebrating science, paneled by wooden decorations symbolizing 14 constellations, symmetrically arranged around a central image of Apollo, the Greek God of Medicine. Apollo is located inside an octagonal frame, which represents an allegory of the sky, and by extension, the entire universe. According to ancient Christian mythology, this

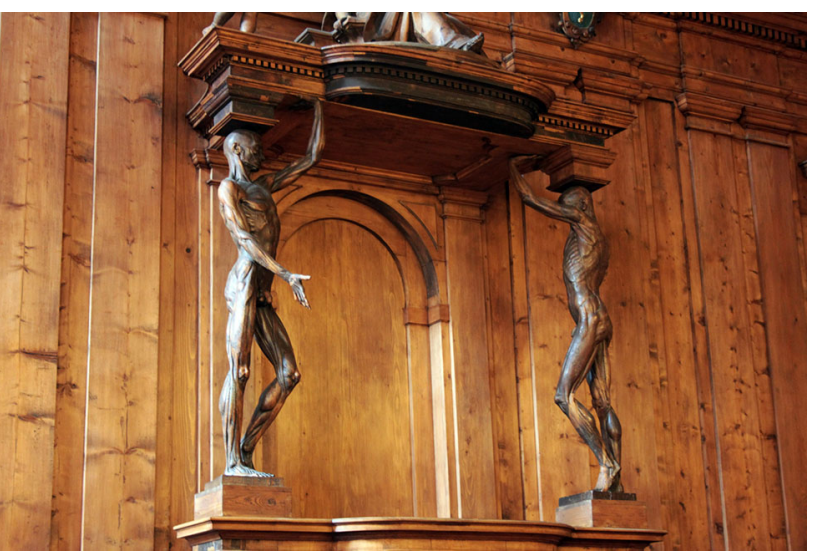

Fig. 2 The "Spellati" (Skinned Men) statues represent the fusion between art and science. Published with permission from Vittorio Tarabella MA. 


\section{Art in Science}

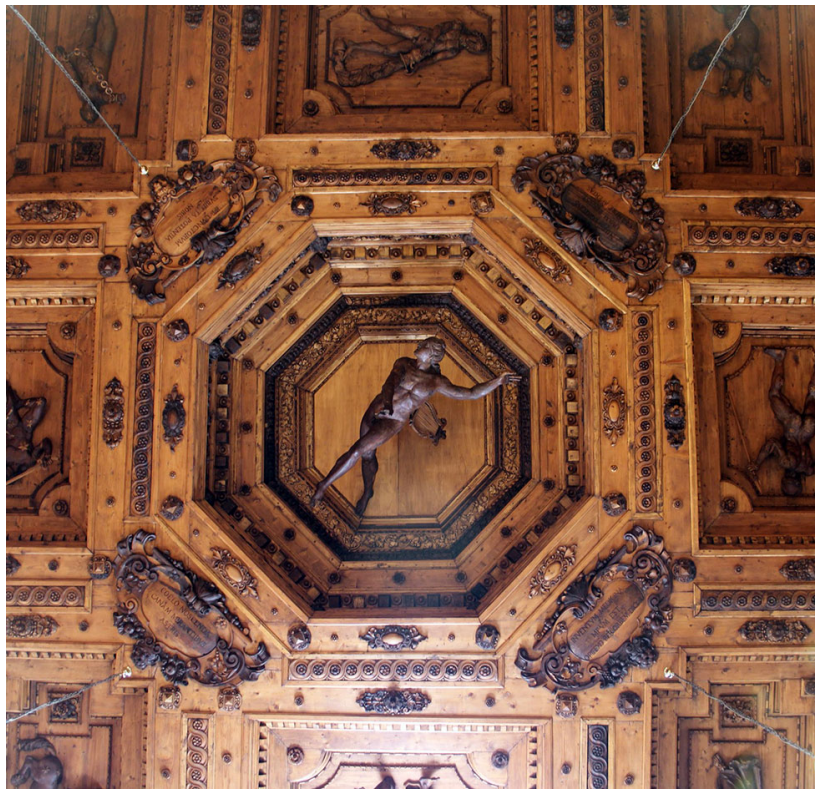

Fig. 3 The ceiling of the Anatomical Theatre features the sculptures of the Greek Gods, including the Greek God of Medicine, Apollo. Published with permission from Vittorio Tarabella MA.

octagonal shape is a symbol for resurrection (not coincidentally, it is the shape of many baptismal fonts) because the number " 8 " symbolizes a "spiritual eighth day of the week," representing the new world after Christ's resurrection. Therefore, the ceiling offers an allegorical representation of the glory of God.

In Apollo's frame, architect Antonio Levanti carved a Latin statement, which translated to English proclaims "I will sing, accompanied by the stars' wonderment, things worth of being known in heaven. Medicine is my invention and, in the world, I am called artist. Nothing is better than seeing everything clearly, and the power of all things is subdued to us" [7]. This statement likely refers to the Arab belief linking the infinite universe (astrology) to finite nature (medicine), as it was customary for physicians to look up and consult the stars before operating on patients or administering drugs [7]. Observers will find, on the North side of the theatre, the constellations of Hydra and Perseus; on the
South side, Boötes and Leo; on the West side, Orion, Andromeda, Aquarius, Sagittarius, and Ophiucus; and Gemini, Centaurus, Hercules, Virgo, and Auriga on the East side. They do not mirror the true astronomical locations of these stars in the sky; rather, they employ a customary placement based on allegory and symbolism.

Below Apollo is the desk where the bodies were dissected by demonstrators, under the guidance of professors of anatomy. Engraved in the floor under the desk, there is a hexagonal shape consisting of six equilateral triangles referring the "physical" man, detached from the unreachable divine. Similarly, the hexagon is the symbol of Venus, who is the embodiment of carnal love. Six is also the number of Venus, according to numerology.

In later years, both because of its beauty and largeness, the Anatomical Theatre lost some of its most practical functions and became a room more dedicated to events like meetings, lectures by distinguished guests, and even the occasional party. Lesser rooms were built next to the anatomical theatre to serve as more functional and reserved working spaces. The University of Bologna itself moved away from the Archiginnasio Palace to find more modern and suitable places to continue its scientific activities. 


\section{Art in Science}

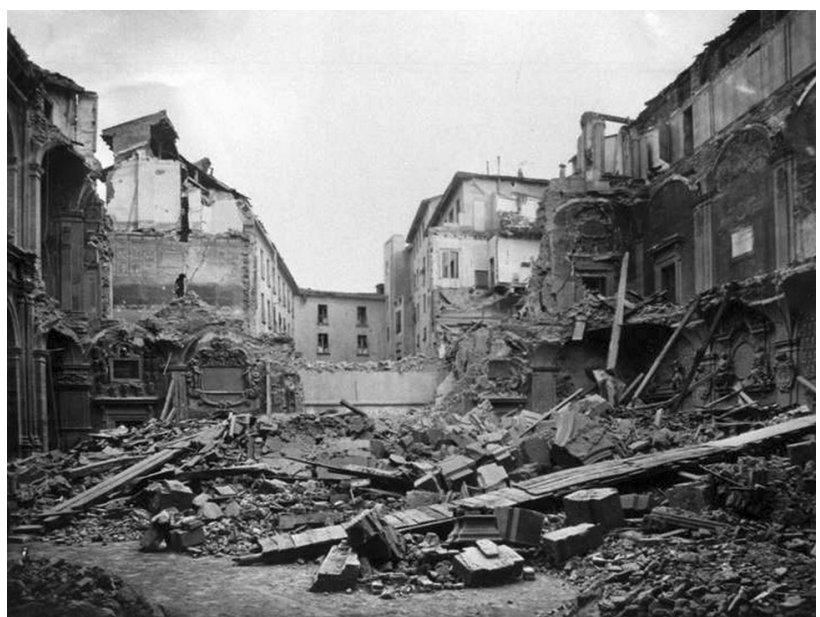

Fig. 4 Bombs destroyed the Anatomical Theatre during WWII. Today, the theatre has been restored. Reproduced with permission from Biblioteca Comunale dell'Archiginnasio.

\section{A Jewel, Nearly Lost}

Although widely considered a jewel of the oldest academic institution of the western world, the Anatomical Theatre could not protect itself against the absurdity of history (Fig. 4). During World War II, Bologna was bombed 94 times because of its strategic importance as a railway junction for northern Italy, and on January 29, 1944, the Archiginnasio Palace was hit and almost completely destroyed [1]. The Anatomical Theatre began its way to resurrection in March 1946. The story of its reconstruction [5] is an uncommon model of human will, genius, and social and institutional commitment. A special laboratory was created to collect and sort the surviving fragments, and documents (images, paintings, and other sources) recovered from the rubble, with the hope of possibly restoring the historical pieces to its original form. Today, visitors from around the world remain captivated by the beauty of the Anatomical Theatre. It now stands as an everlasting testimony of the strong connection between art and science.

Acknowledgments The authors would like to thank Liliana Draghetti (Donazione Putti, Biblioteche Scientifiche, Rizzoli Orthopaedic Institute, Bologna, Italy), Maurizio Avanzolini, Anna Manfron, and Sonia Venturi (Biblioteca Comunale dell'Archiginnasio,
Bologna, Italy), Emil Ferretti (Biomechanics Lab, Rizzoli Orthopaedic Institute), and Keith Smith for their help on this paper.

\section{References}

1. Bologna Bombardata 1943-1945. Available at: http://badigit.comune. bologna.it/bolognabombardata/index. html. Accessed February 9, 2015.

2. Di Matteo B, Tarabella V, Filardo G, Viganò A, Tomba P, Marcacci M. Art in science: Giovanni Paolo Mascagni and the art of anatomy. Clin Orthop Relat Res. 2015;473:783-788.

3. Di Matteo B, Tarabella V, Filardo G, Viganò A, Tomba P, Marcacci M. Art and science in the Renaissance: The case of Walther Hermann Ryff. Clin Orthop Relat Res. 2014;472:1689-1696.

4. Friedlaender GE, Friedlaender LK. Art in science: The Gross Clinic by Thomas Eakins. Clin Orthop Relat Res. 2014;472:3632-3636.

5. Pascolutti F. Il palazzo dell'Archiginnasio (1562-1563) di Bologna 1944-1945; 1946-1957. In: Pascolutti F. Alfredo Barbacci: The Superintendent and the Restorer, an Architect of the Post-War Reconstruction [in Italian]. Argelato, Italy: Minerva; 2011:143-164.

6. Ridder-Symoens H. A History of the University in Europe: Volume 1, Universities in the Middle Ages. Cambridge, UK: Cambridge University Press; 2003:6.

7. Roncuzzi Roversi Monaco V. Il Teatro Anatomico. In: Roncuzzi Roversi Monaco R. The Archiginnasio: Guide to the Palace and the 


\section{Art in Science}

Library [in Italian]. Bologna, Italy: Nuova Alfa; 1988:35-43.

8. Roversi G. Il Teatro Anatomico. In: Roversi G. The Archiginnasio. The Palace, the University, the Library [in Italian]. Bologna, Italy: Grafis, 1988:201-218.

9. Turney BW. Anatomy in a Modern Medical Curriculum. Ann $R$ Coll Surg Engl. 2007;89:104-107.
10. Vesalius A. On the Fabric of the Human Body in Seven Books [in Latin]. Basilex: ex officina Joannis Oporini, 1543. 